\title{
MIR551A Gene
}

National Cancer Institute

\section{Source}

National Cancer Institute. MIR551A Gene. NCI Thesaurus. Code C128929.

This gene plays a role in the inhibition of targ et gene expression. 